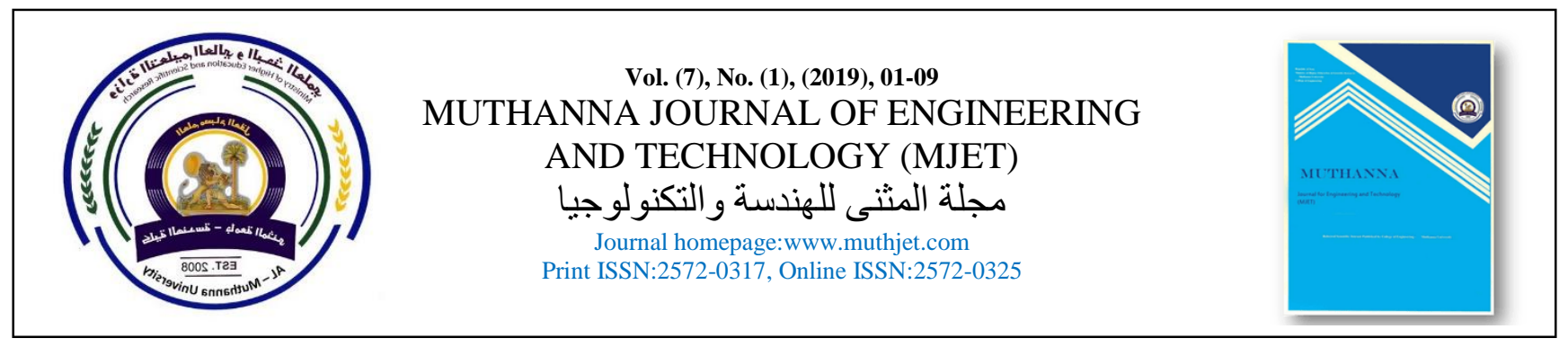

\title{
THE ULTIMATE SHEAR STRENGTH OF SCC BEAMS STRENGTHENED BY INCLINED CFRP STRIPS
}

\section{Sarmad Sh. Abdulqadera ${ }^{a}$ Ragheed F. makki ${ }^{b}$ and Mohanad W. Mousa ${ }^{c^{*}}$}

a Assistant Professor, Building and Construction Engineering Department, University of Technology.

${ }^{\mathrm{b}}$ Assistant Professor, Civil Engineering Department, Faculty of Engineering, University of Kufa.

${ }^{\mathrm{c}}$ Postgraduate Student at Building and Construction Engineering Department, University of Technology.

\section{ARTICLE INFO}

Received: $20 / 01 / 2018$

Accepted: 25/03/2018

\section{Keywords}

Self-Compacting Concrete,

shear strength, Reinforced

Concrete, CFRP Strips

\begin{abstract}
This paper presents an experimental study of structural behavior of selfcompacting reinforced concrete beams strengthened in shear by inclined CFRP strips. The experimental work consists of casting and testing of nine simply supported reinforced concrete beams. In this study, three parameters were considered, the configuration of CFRP sheets wrapping system, i.e two sides and U-shape, effect of horizontal strap of CFRP strips and CFRP strengthening area. The results showed that the presence of the horizontal strap of CFRP strips on the inclined strips increases the shear strength and the ultimate carrying load capacity by 8 to $15 \%$ and 7 to $10 \%$, respectively in compare with the wrapping system of the CFRP strips.
\end{abstract}




\section{Introduction}

Self-Compacting Concrete (SCC) is important developments in concrete technology. It is a new type of high performance concrete with the ability to flow under its weight and without the need for vibrations. Recently, a large local interest towards self-compact concrete has been derived [1]. SCC is a relatively new type of concrete that is highly flowable and non-segregating. It does not require vibration when cast, is capable of flowing through narrow opening or extremely congested reinforcement, and provides a void-free surface. It is also known as self-consolidating concrete, selfleveling concrete and high fluidity concrete [2]. SCC flows like "honey" and has nearly a horizontal concrete level after placing. When SCC is placed in a form, its motion may be a creeping movement or a rapid flow. Because of this style of flow, the surface finish between the form and the concrete can be exceptionally smooth, creating a muchimproved from finish over conventional concrete [3]. Also, SCC can also be used in situations where it is difficult or impossible to use mechanical compaction such as pile foundations casting in site, underwater concreting, machine bases and walls or columns with congested reinforcement. The high flowability of SCC makes it able to fill the formwork without using any vibration [4].

Fiber reinforced polymers, (FRP), are what many people refer to as composites. The word composite comes from the Latin word componere, which means put together. A composite is a material formed from two or more separate parts with a distinguished phase between them. Consequently, there are plenty of composites available in material - Composite will in the following refer to fiber reinforced polymers. This is a composite where a polymer matrix is reinforced with many relatively thin and long Fiber s [5].

The three main types of FRP used in the construction industry are: aramid (AFRP), carbon (CFRP) and glass (GFRP) [6]. The advantages of CFRP application include high strength to weight ratio, flexibility and available in long lengths, rapid execution on site, high elastic modulus, high dynamic strength and no need for special equipment $[6,7]$. As stated in the ACI Committee 440.2R-08 [8], there are three types of wrapping patterns are used to increase the shear strength of beams, or columns. Completely wrapping system of FRP around the structural member on all sides is the most efficient and common wrap scheme for columns. However, the overall wrapping is not practical from the construction point of view in the case of beam applications where the integrated slab makes it impractical to completely wrap the member; the shear strength can be improved by wrapping the FRP system around three sides of the member (U-wrap) or bonding to two opposite sides of the member $[8,9]$.

Figure 1 shows the direction of FRP. Orienting FRP fibers transverse to the axis of the member or perpendicular to the potential shear cracks is more effective in providing additional shear strength [10]. Fibers may be oriented in such a way as to promote better diagonal tension cracks. This is achieved by using inclined strips.

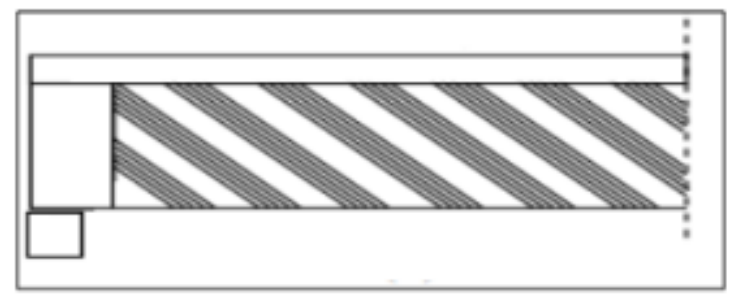

Figure 1. FRP directions [10]

CFRP can be discovery in many nomenclatures, for example: laminates, strips, plates, sheets, and fabrics. The application of externally bonded FRP sheets is an appropriate repair and enhancement method that has become a more accepted practice in the structural sector $[11,12]$.

Because of that the FRP is anisotropic material with high strength in the direction of the fibers, the fibers may be oriented in such a way to best reinforce against diagonal tension cracks. This is achieved by the use of inclined strips. However, vertical plies are easier to be installed just as with the case of vertical and inclined stirrups [13].

Meshfeq [14] test program consists of ten RC continuous (two-span) beams, the investigation includes parametric studies for CFRP sheet strengthening such as their location (two, three and four sides), orientation and keeping the amount of CFRP sheet for all strengthened beams constant.

\section{Experimental program}

The experimental program consists of testing nine simply supported beams molded by using SCC with two point loads. All beams have the same dimensions, flexural reinforcement and shear reinforcement. These beams were designed to avoid the flexural failure so that the failure is governed by shear. The variables investigated in this work includes CFRP strips amount and distribution.

The specimens were divided into two groups, I,e A and B. All Groups with (shear span to effective depth ratio $(\mathrm{a} / \mathrm{d})$ ) equal to 2.37. Eight SCC beams strengthened by CFRP, and the nine beam did not strengthened by CFRP strips and selected as reference beam. All nine beams were casted using SCC with compressive strength $\left(f^{\prime} c\right)$ equals to $36.5 \mathrm{MPa}$. 


\section{Details of tested beams}

The overall length of the beams is $1500 \mathrm{~mm}$ with clear span of $1400 \mathrm{~mm}$, whilst the width and height are $150 \mathrm{~mm}$ and $250 \mathrm{~mm}$, respectively, as shown in (Fig. 2). All beams were longitudinally reinforced with two bars of $16 \mathrm{~mm}$ diameter and one bar of 12 $\mathrm{mm}$ diameter placed at the tension side with clear cover of $25 \mathrm{~mm}$. At the top face, two bars of $6 \mathrm{~mm}$ diameter were provided. For vertical shear reinforcement, deformed bars of $6 \mathrm{~mm}$ diameter were provided at a spacing of $250 \mathrm{~mm}$ center to center.

\section{Specimen identification and strengthening schemes}

Strengthened beams schemes by one layer of CFRP strips with constant width $(40 \mathrm{~mm})$. The thickness of this strip was $(0.166 \mathrm{~mm})$ as provided by the manufacturers, were chosen carefully based on the field conditions and the practical needs, mainly, economic and crack pattern. In this study, where the letter B indicates beam specimen, C indicates control specimen, the letter I indicates inclined strengthening, letter $\mathrm{H}$ indicates horizontal strengthening and the letter U Indicates U-shape strengthened. While the numbers ( 2 and 3 ) represent number of strips. The first beam control (BC) has not strengthened by CFRP. The following strengthening layouts were applied:

1- Group (A): contains four beams as following:

i. The beam $\left(\mathrm{BI}_{2}\right.$ and $\left.\mathrm{BI}_{3}\right)$ were provided with two and three inclined strips at each side, the strips were installed at angle of $45^{\circ}$ along shear span, as shown in (Figs. 3 and 4 ).

ii. The beam $\left(\mathrm{BI}_{2} \mathrm{H}_{2}\right.$ and $\left.\mathrm{BI}_{3} \mathrm{H}_{2}\right)$ were provided with two and three inclined strips at each side, in addition to two horizontal strips placed at the end of the upper and lower along shear span, as shown in (Figs. 5 and 6).

2- Group (B): contains four beams as following:

i. The beam $\left(\mathrm{BI}_{2} \mathrm{U}\right.$ and $\left.\mathrm{BI}_{3} \mathrm{U}\right)$ were provided with two and three inclined U-shape strips at each side, the strips were installed at angle of $45^{\circ}$ along shear span, as shown in (Figs. 3 and 4 ).

ii. The beam $\left(\mathrm{BI}_{2} \mathrm{UH}_{1}\right.$ and $\left.\mathrm{BI}_{3} \mathrm{UH}_{1}\right)$ were provided with two and three inclined U-shape strips at each side, in addition to one horizontal strip placed at the end of the upper along shear span, as shown in (Figs. 7 and 8).

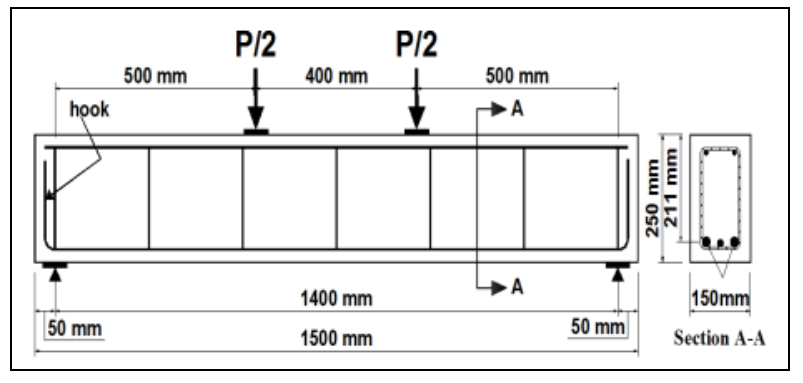

Figure 2. Dimensions and details of tested beams

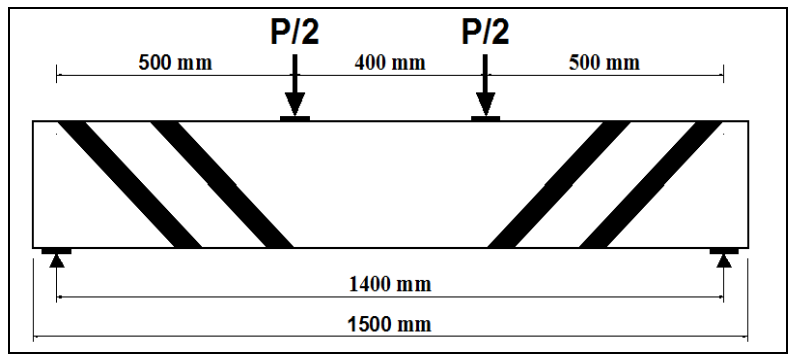

Figure 3. Shear Strengthening for beams $\left(\mathrm{BI}_{2}\right.$ and $\left.\mathrm{BI}_{2} \mathrm{U}\right)$

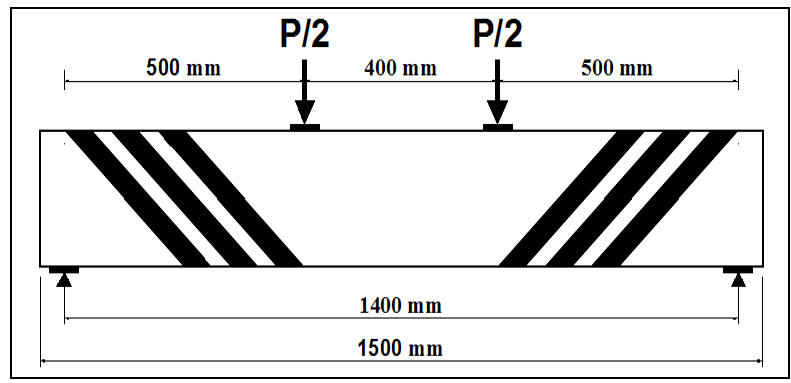

Figure 4. Shear Strengthening for beams $\left(\mathrm{BI}_{3}\right.$ and $\left.\mathrm{BI}_{3} \mathrm{U}\right)$

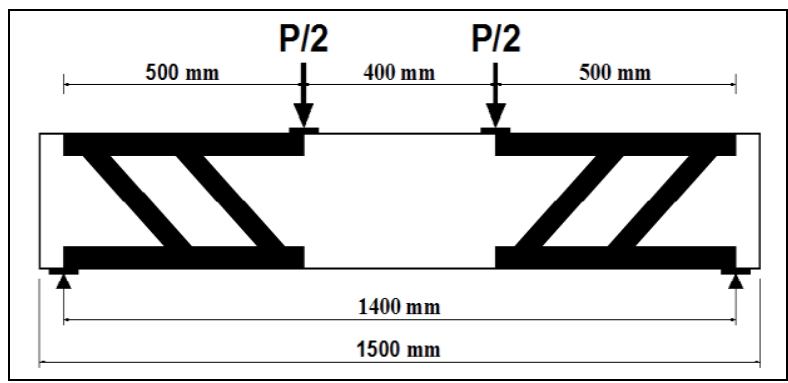

Figure 5. Shear Strengthening for beam $\left(\mathrm{BI}_{2} \mathrm{H}_{2}\right)$

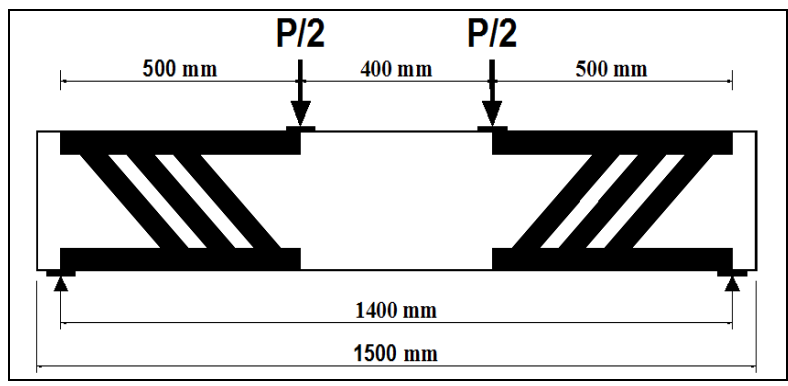

Figure 6. Shear Strengthening for beam $\left(\mathrm{BI}_{3} \mathrm{H}_{2}\right)$ 


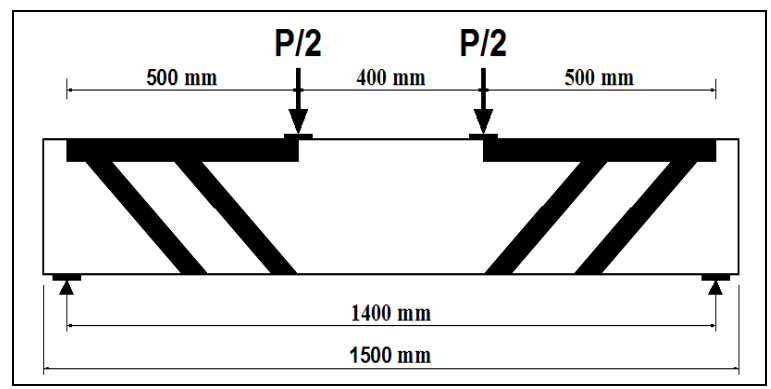

Figure 7. Shear Strengthening for beam $\left(\mathrm{BI}_{2} \mathrm{UH}_{1}\right)$

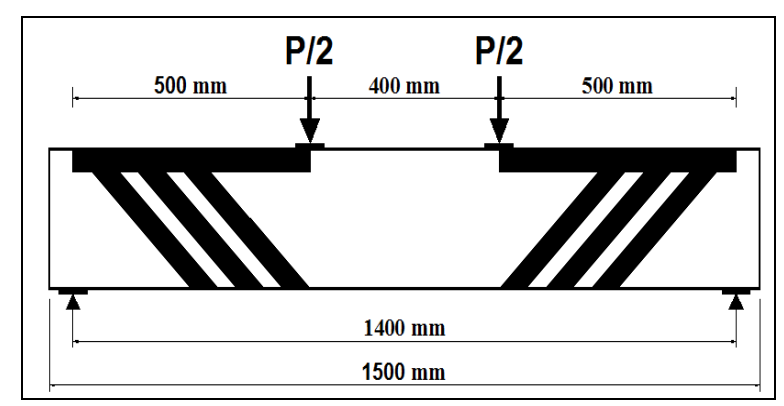

Figure 8. Shear Strengthening for beam $\left(\mathrm{BI}_{3} \mathrm{UH}_{1}\right)$

\section{Materials}

The properties of cement, aggregate, admixture, carbon fiber reinforced polymer CFRP and epoxy used in this investigation are presented in this section.

\section{Cement}

Ordinary Portland Cement OPC (Crista) was used in this study. It complies with the Iraqi specification (IQS) No. 5/1984 [15]. The laboratory test result of this type of cement illustrates its physical properties as: The compressive strength at 3 days and 7 days were equal to 19 and $28 \mathrm{MPa}$, respectively.

\section{Fine aggregate (Sand)}

Natural sand from (Al-Akaidur) region was used for concrete mixes in this study. The fine aggregate was passing from sieve $(4.75 \mathrm{~mm})$ maximum size; and remaining on sieve $(0.15 \mathrm{~mm})$. The obtained results indicated that the fine aggregate grading were within the requirements of Iraqi specification No. 45/1984 [16]. The main properties of the fine sand used are: The sulfate content is equal to $0.08 \%$, Absorption is equal to $0.75 \%$ and Specific gravity is equal to 2.6 .

\section{Coarse aggregate}

The rounded coarse aggregate from Al-Niba'ee quarry is used maximum aggregate size of (14 $\mathrm{mm})$. The results obtained indicate that the classification of coarse aggregates was within the requirements of Iraqi Standards No.45/1984 [16]. The main properties of the coarse aggregate used are: The sulfate content is equal to $0.03 \%$,
Absorption is equal to $0.5 \%$ and Specific gravity is equal to 2.65 .

\section{Limestone powder (LSP)}

This substance is locally called as "Al-Ghubra", which was brought from the Darbindkhan plant area and has been used as a filler for concrete production for many years. The particle size of LSP less than $0.125 \mathrm{~mm}$ (sieve No.200) was used in the current research work, and the chemical composition is listed in Table 1.

Table 1. Chemical Composition of ( LSP)*

\begin{tabular}{cc}
\hline Oxide composition & \% by weight \\
\hline $\mathrm{CaO}$ & 54.10 \\
$\mathrm{SiO}$ & 1.38 \\
$\mathrm{MgO}$ & 0.13 \\
$\mathrm{Fe}_{2} \mathrm{O}_{3}$ & 0.12 \\
$\mathrm{Al}_{2} \mathrm{O}_{3}$ & 0.72 \\
$\mathrm{SO}_{3}$ & 0.21 \\
Loss on Ignition & 42.56 \\
\hline * Chemical analysis were conducted by the materials laboratory \\
in the College of Engineering University of Kufa
\end{tabular}

\section{Superplasticizer (SP)}

In this work, superplasticizer was used to obtain fresh properties of SCC according to ASTM C494/C494M-15 [17] types $A$ and $F$, and commercially known as " GLENIUM54". The normal dose of Glenium54 is $(0.5$ - 2.5) liter / 100 $\mathrm{kg}$ of cement.

\section{Steel Reinforcing Bars}

Deformed steel bars (16, 12 and 6) $\mathrm{mm}$ in diameter were used in this work. Three samples of each bar were tested under tension. The tensile tests of reinforcing steel were conducted according to ASTM A1064/A1064N-14 [18] and ASTM A615/A615M-15a [19]. The mechanical properties of steel are listed in Table 2.

Table 2. Properties of reinforcing steel *

\begin{tabular}{ccc}
\hline $\begin{array}{c}\text { Bar } \\
\text { Diameter } \\
(\mathbf{m m})\end{array}$ & $\begin{array}{c}\text { Yield Stress } \\
(\mathbf{M P a}) * *\end{array}$ & $\begin{array}{c}\text { Ultimate Strength } \\
(\mathbf{M P a}) * *\end{array}$ \\
\hline 6 & 533 & 664 \\
12 & 548 & 693 \\
16 & 572 & 748 \\
\hline
\end{tabular}

* The test was carried by using the testing machine available in the Consulting Bureau Laboratory in College of Engineering University of Kufa.

** Each value is an average of three specimens (each $40 \mathrm{~cm}$ length).

\section{Carbon fiber reinforced polymers (CFRP)}

When CFRP is loaded in tension, it doesn't show any plastic behavior (yield) before rupture. Sika Wrap ${ }^{\circledR} 300 \mathrm{C} / 60$ was used to enhance external testing SCC beams. The mechanical properties of CFRP sheet are tabulated in Table 3. 
Table 3. Technical Properties of CFRP Sheet*

\begin{tabular}{cc}
\hline Properties & SikaWarp $^{\circledR}$-300 C/60 \\
\hline Tensile strength (MPa) & 3900 \\
Elongation at break $(\%)$ & 1.5 \\
Density $\left(\mathrm{g} / \mathrm{cm}^{3}\right)$ & 1.79 \\
Tensile E-modulus & 230000 \\
$(\mathrm{MPa})$ & 50 \\
Width $(\mathrm{cm})$ & 0.166 \\
Thickness $(\mathrm{mm})$ & 300 \\
Weight $\left(\mathrm{g} / \mathrm{m}^{2}\right)$ & \\
\hline
\end{tabular}

*Supplied by the manufacturer

\section{Bonding Materials}

The most suitable adhesives with CFRP sheets are Sikadur ${ }^{\circledR} 330$. The adhesive type consists of two compounds, compound A (white) and compound B (gray). The mix ratio is $4: 1$ as $\mathrm{A}$ : $\mathrm{B}$. Its main characteristics as provided by the manufacturer are shown in Table 4.

Table 4. Properties of Adhesive Material*

\begin{tabular}{cc}
\hline Properties & Sikadur ${ }^{\circledR-330}$ \\
\hline Tensile strength $(\mathrm{MPa})$ & 30 \\
Elongation at break $(\%)$ & 0.9 \\
Density $(\mathrm{kg} / \mathrm{l})$ & Mixed Resin: 1.31 \\
E-modulus $(\mathrm{MPa})$ & Flexural:3800 \\
Open time (min.) & Tensile: 4500 \\
Full cure (days) & $30\left(\mathrm{at}+35^{\circ} \mathrm{c}\right)$ \\
*Supplied by the manufacturer & $\mathbf{7}\left(\mathrm{at}+35^{\circ} \mathrm{c}\right)$ \\
\hline
\end{tabular}

\section{SCC Mix Design}

To meet the self-compacting requirements and the designed compressive strength, five trial mixes were conducted. The SCC mix is designed according to EFNARC [20]. Table 5 lists the final mix ratios of SCC mix.

\section{Mixing and curing of Concrete Batches}

Mixing procedure is important to obtain the required workability and homogeneity of SCC. The method used to mix the materials is summarized as follows:

- The fine aggregate was added to the mixer with a quantity of one third from the (water and dosage of superplasticizer well as mixed together) and mixed for one minute.

- The powder (Cement and LSP) were added with one third amount from (water and dosage of super plasticizer well as mixed together). The mixture is then mixed for one minute.

- The coarse aggregate was added with the last one third amount of (water and dosage of super plasticizer well as mixed together), and mixing extends for one and half minute.

After the mixing process was completed, the main specimens were casted into molds without the need for vibration as the concrete molds were easily filled and interspersed between reinforcement bars without segregation. The hardened specimens were demolded after 48 hours and burlap sacks were monitored and kept wet until twenty eight full days passed.

Table 5. Details of SCC mix

\begin{tabular}{cc}
\hline Materials & Amount \\
\hline Cement $\left(\mathrm{kg} / \mathrm{m}^{3}\right)$ & 350 \\
Fine Aggregate $\left(\mathrm{kg} / \mathrm{m}^{3}\right)$ & 797 \\
Coarse Aggregate $\left(\mathrm{kg} / \mathrm{m}^{3}\right)$ & 767 \\
Limestone $\left(\mathrm{kg} / \mathrm{m}^{3}\right)$ & 170 \\
Water $(1 /)$ & 150 \\
GLENIUM 54 $\left(1 / \mathrm{m}^{3}\right)$ & 4.2 \\
W/P* & 0.29 \\
W/C & 0.43 \\
\hline * W/P = Water/Powder, Powder = Cement + Limestone
\end{tabular}

\section{Strengthening with CFRP}

The strengthening system used in this work comprised of fiber strips and epoxy. All the strengthening processes were done after 28 days of moist curing for the beam specimens. Only the first specimen (BC) was kept without strengthening as a control specimen, whereas the other eight specimens were strengthened with externally applied CFRP strips. The following different schemes illustrate the technique of this strengthening as shown in (Figs. 3 to 8).

\section{Results and Discussion}

The nine beams were tested in this study, including one reference beam. While eight SCC beams strengthened by CFRP, were divided into two groups. The cracking load, ultimate load and mid span deflections at first cracking and ultimate stages are listed in Table 6. 
Table 6. Experimental results of the tested beams

\begin{tabular}{|c|c|c|c|c|c|c|c|c|c|}
\hline \multirow{2}{*}{ 冚 } & \multirow{2}{*}{ No. } & \multirow{2}{*}{$\begin{array}{c}\text { Beam } \\
\text { designation }\end{array}$} & \multicolumn{4}{|c|}{$\begin{array}{c}\text { Total applied load } \\
(\mathbf{k N})\end{array}$} & \multicolumn{2}{|c|}{$\begin{array}{c}\text { Mid-span } \\
\text { deflection } \\
(\mathrm{mm})\end{array}$} & \multirow{2}{*}{$\begin{array}{c}\text { Percentage } \\
\text { increase in } \\
\text { ultimate load } \\
\text { with respect to } \\
\text { reference beam }\end{array}$} \\
\hline & & & $\boldsymbol{P}_{\boldsymbol{c}(f)^{*}}$ & $\boldsymbol{P}_{c(s)} * *$ & $\boldsymbol{P}_{u}$ & $\begin{array}{c}\mathbf{P}_{\mathbf{c r}} / \mathbf{P}_{\mathbf{u}} \\
\%\end{array}$ & $\Delta_{c(f)}$ & $\Delta_{\mathbf{u}}$ & \\
\hline \multirow[t]{2}{*}{-} & 1 & $\mathrm{BC}$ & 20 & 25 & 152 & 16.45 & 0.93 & 8.86 & - \\
\hline & 2 & $\mathrm{BI}_{2}$ & 25 & 40 & 205 & 19.51 & 1.02 & 9.94 & $34.87 \%$ \\
\hline \multirow{3}{*}{ A } & 3 & $\mathrm{BI}_{3}$ & 25 & 50 & 223 & 22.42 & 0.94 & 10.62 & $46.71 \%$ \\
\hline & 4 & $\mathrm{BI}_{2} \mathrm{H}_{2}$ & 30 & 60 & 230 & 26.1 & 1.33 & 10.57 & $51.32 \%$ \\
\hline & 5 & $\mathrm{BI}_{3} \mathrm{H}_{2}$ & 40 & 60 & 240 & 25 & 1.44 & 10.41 & $57.89 \%$ \\
\hline \multirow{4}{*}{ B } & 6 & $\mathrm{BI}_{2} \mathrm{U}$ & 25 & 40 & 220 & 18.18 & 0.75 & 9.71 & $44.74 \%$ \\
\hline & 7 & $\mathrm{BI}_{3} \mathrm{U}$ & 25 & 50 & 245 & 20.41 & 0.91 & 10.07 & $61.18 \%$ \\
\hline & 8 & $\mathrm{BI}_{2} \mathrm{UH}_{1}$ & 30 & 50 & 240 & 20.83 & 0.94 & 10.61 & $57.89 \%$ \\
\hline & 9 & $\mathrm{BI}_{3} \mathrm{UH}_{1}$ & 40 & 75 & 282 & 25.6 & 1.12 & 12.56 & $85.53 \%$ \\
\hline
\end{tabular}

of first flexural

\section{General Behavior and Crack Patterns}

In general, all the tested beams almost exhibit the same behavior from the initial loading up to the load causing failure. Cracking of each specimen was generally progressed as follows:

With the increase of loading a small flexural crack appears at or near the mid-span of the beam then it extended upward. With further loading an inclined crack appears at shear zone approximately at the mid-length of load path.

It can be observed that the beams without strengthening almost show the same crack pattern and failure mechanism as strengthened beams but differ in the ultimate loads. The difference in cracking patterns depend on the amount and shape of CFRP sheets as shown in (Figs 9 to 11).

\section{First Cracking and Ultimate Loads}

The first cracking load increases with increase amount of CFRP and change the shape of strengthened as shown in Table 6. The diagonal crack that causing failure initiated suddenly from the last shear crack that became inclined and crossed mid depth, and then such a crack propagated simultaneously towards the load-point and towards the support along the tensile reinforcement (due to dowel action) causing a loss of bond and failure of the beam. External strengthening of SCC beams by CFRP sheets showed improvement in first cracking loads when compared with the control beam as shown in Table 6 with same load level.

From comparison of the four specimens in group A, it can be seen that the ultimate load carrying capacity increases with the increase the number of the inclined CFRP strips distributed between the support and the point of concentrated load. On the other hand, when two horizontal CFRP strips were connected to the inclined CFRP strips to prevent the

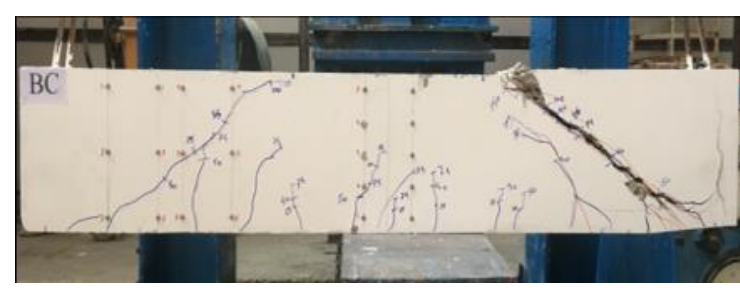

Figure 9. Crack pattern for the beams failed in shear for beam (BC)

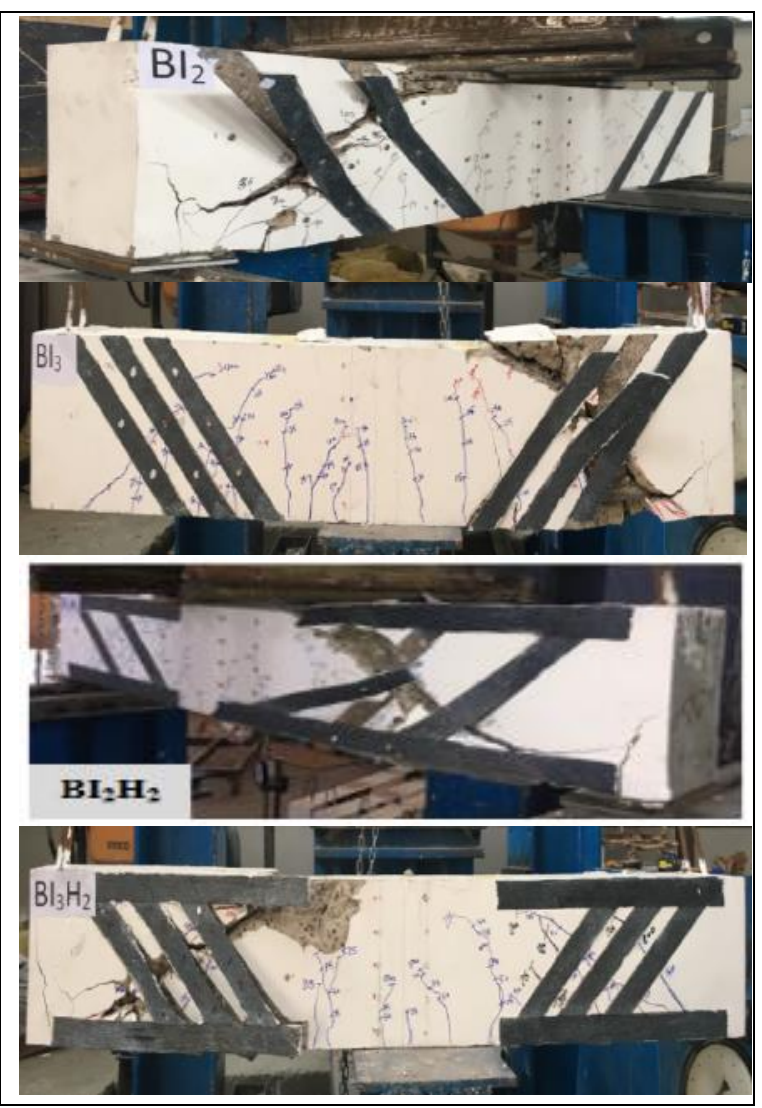

Figures 10. Crack pattern for the beams failed in shear for group (A) 


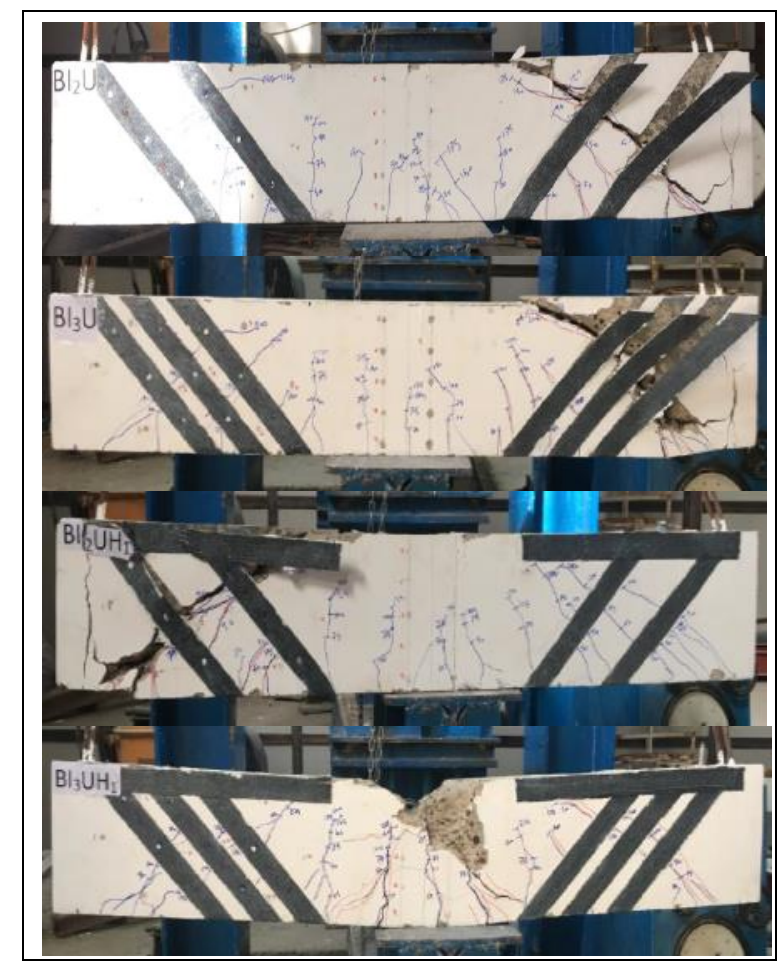

Figures 11. Crack pattern for the beams failed in shear for beams $\left(\mathrm{BI}_{2} \mathrm{U}, \mathrm{BI}_{3} \mathrm{U}\right.$ and $\left.\mathrm{BI}_{2} \mathrm{UH}_{1}\right)$ and failed in flexural for beam $\left(\mathrm{BI}_{3} \mathrm{UH}_{1}\right)$

failure of the latter by de-bonding, an increase was made in the ultimate load compared to the beams without horizontal CFRP strips.

The specimens in this group failed suddenly by de-bonding and rupture of CFRP strips, while from comparison of the four specimens in group B, it can be seen that the ultimate loads capacity increased with the increasing of inclined the U-shape CFRP strips distributed between the support and the point of concentrated load. Whilst, when one horizontal CFRP strip were connected to the inclined U-shape CFRP strips to prevent the failure of the latter by debonding, an increase was made in the ultimate load compared to the beams without horizontal CFRP strip. The specimens in this group failed suddenly by de-bonding and rupture of CFRP strips.

The beam $\left(\mathrm{BI}_{3} \mathrm{UH}_{1}\right)$ gave a better improvement in strength than previous beams. This improvement indicates the presence of CFRP strips in the form of inclined U- shape with horizontal CFRP strips. This is due to the presence of these strips perpendicularly on the crack pattern. Also, the presence of CFRP strips gave another advantage, as the shear cracks were small in width and spaced while the bending incisions were larger and deeper. This was a reason for combination failure shear and flexural, as well as concrete crushing in the compression zone. Figure 12 show results of groups (A and B) tests conducted as given above and compared with control beam. The percentage increase in ultimate load with respect to reference beam as follows:
$34.87 \%$ to $57.89 \%$ for group A and $44.74 \%$ to $85.53 \%$ for group B.

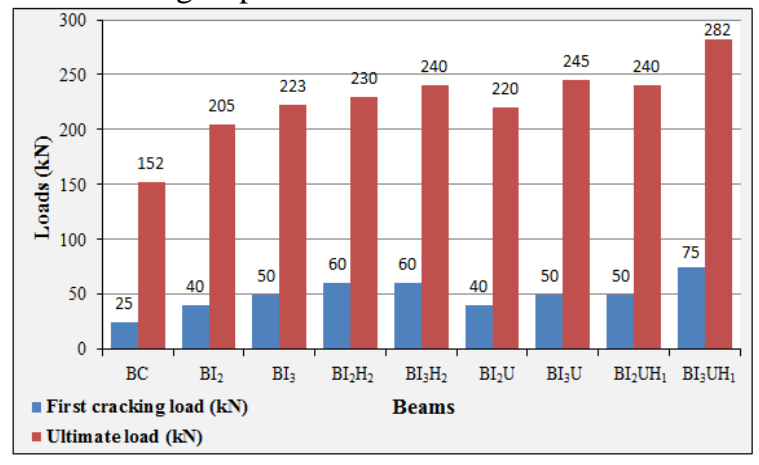

Figure 12. First Cracking and Ultimate Loads for groups (A and B) with the reference Specimen (BC)

\section{Load deflection Behavior}

Experimental load versus mid-span deflection curves for these SCC beams are presented in this section as shown in (Figs. 13 and 14). These Figures show that the load-deflection curve for the groups A and B, whilst (Fig. 15) shows comparison the loaddeflection curves for SCC beams strengthened with CFRP for beams $\left(\mathrm{BI}_{2}\right.$ and $\left.\mathrm{BI}_{3}\right)$ with $\left(\mathrm{BI}_{2} \mathrm{U}\right.$ and $\left.\mathrm{BI}_{3} \mathrm{U}\right)$ respectively, while the (Fig. 16) illustrates comparison the load-deflection curves for SCC beams strengthened with CFRP for beams $\left(\mathrm{BI}_{2} \mathrm{H}_{2}\right.$ and $\left.\mathrm{BI}_{3} \mathrm{H}_{2}\right)$ with $\left(\mathrm{BI}_{2} \mathrm{UH}_{1}\right.$ and $\left.\mathrm{BI}_{3} \mathrm{UH}_{1}\right)$ respectively. Obviously, it was noticed that the presence of CFRP sheets affected the behavior of strengthened beams compared with the control beams by increasing the ultimate strength and reducing the ultimate central deflection.

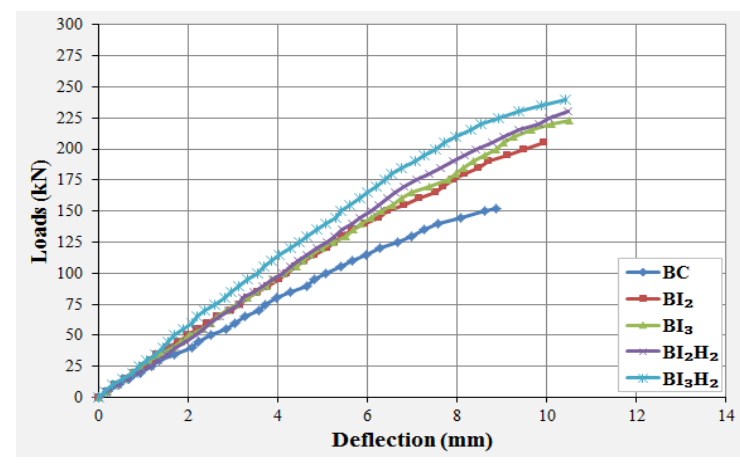

\section{Figure 13. Load-Deflection Curve for group A}

The ultimate load for (BC) is equal to $152 \mathrm{kN}$, the value of deflection at this load is equal to 8.86 $\mathrm{mm}$. For group(A) the ratio of deflection for the strengthened beams to that of the control beams ranged were $(0.271,0.297,0.313$ and 0.388$)$ for the beam specimens $\left(\mathrm{BI}_{2}, \mathrm{BI}_{3}, \mathrm{BI}_{2} \mathrm{H}_{2}\right.$ and $\left.\mathrm{BI}_{3} \mathrm{H}_{2}\right)$ respectively, while for group (B) the ratio of deflection for the strengthened beams to that of the control beams ranged were $(0.352,0.385,0.383$ and $0.446)$ for the beam specimens $\left(\mathrm{BI}_{2} \mathrm{U}, \mathrm{BI}_{3} \mathrm{U}, \mathrm{BI}_{2} \mathrm{UH}_{1}\right.$ and $\mathrm{BI}_{3} \mathrm{UH}_{1}$ ) respectively. 


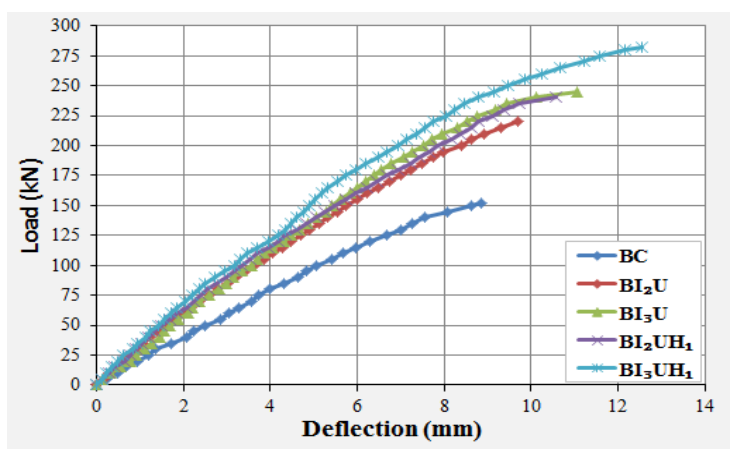

Figure 14. Load-Deflection Curve for group B

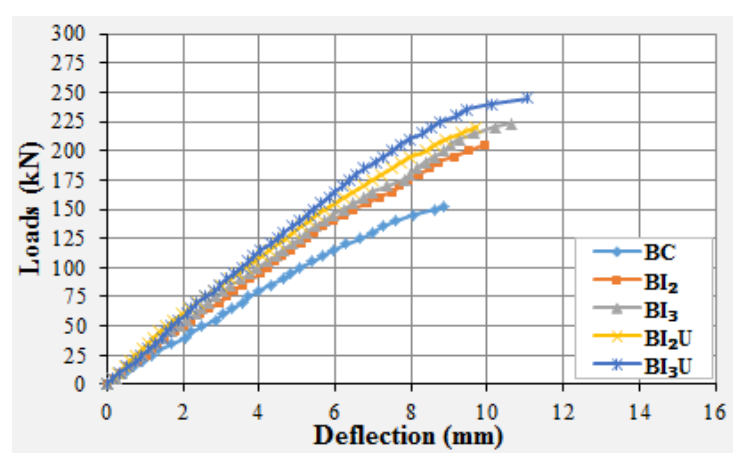

Figure 15. Load-Deflection Curve of Specimens $\left(\mathrm{BI}_{2}, \mathrm{BI}_{3}, \mathrm{BI}_{2} \mathrm{U}\right.$ and $\left.\mathrm{BI}_{3} \mathrm{U}\right)$

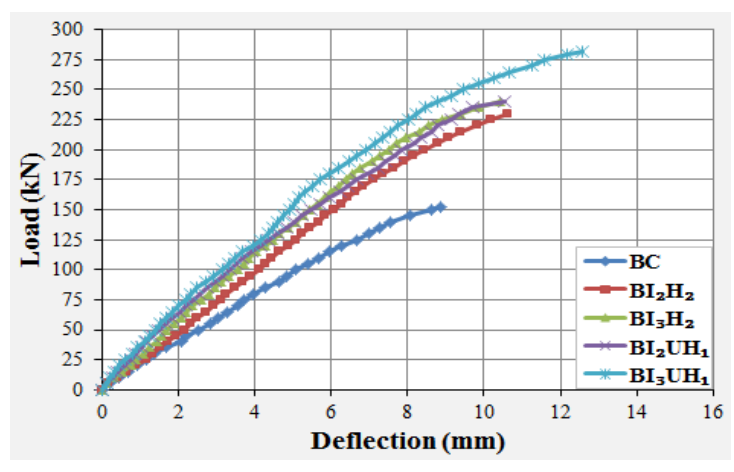

Figure 16. Load-Deflection Curve of Specimens $\left(\mathrm{BI}_{2} \mathrm{H}_{2}, \mathrm{BI}_{3} \mathrm{H}_{2}, \mathrm{BI}_{2} \mathrm{UH}_{1}\right.$ and $\left.\mathrm{BI}_{3} \mathrm{UH}_{1}\right)$

\section{Shear Crack Width}

Shear cracking load is defined as the load at which the first major inclined diagonal tension crack appears in the shear span. The crack is sudden originated at the middle of the shear span and propagates toward the support and loading point during subsequent increase in the applied load. Maximum crack widths along the major inclined crack in the shear span occurred almost at mid depth of the beam. Beams without CFRP strips exhibited considerably larger crack width at failure.

For each load increment, crack width of the major inclined crack at mid-depth of the beam was measured by means of crack detection pocket microscope. Figures 17 to 19 show the behavior of the total applied load versus the maximum crack for the control beam BC and beams for groups A and B.

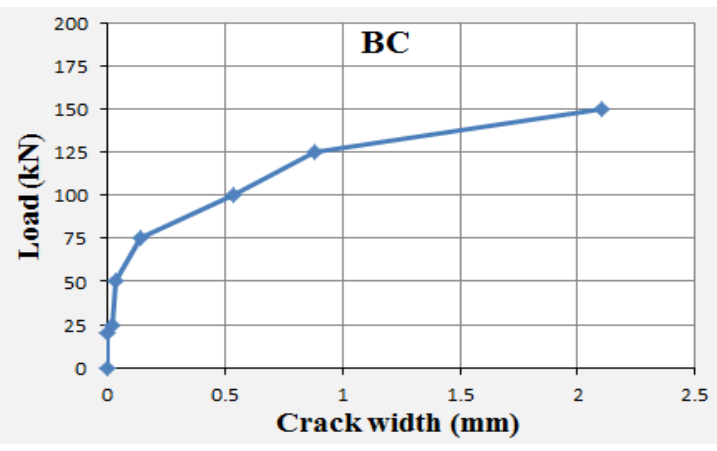

Figure 17. Load versus crack width of BC

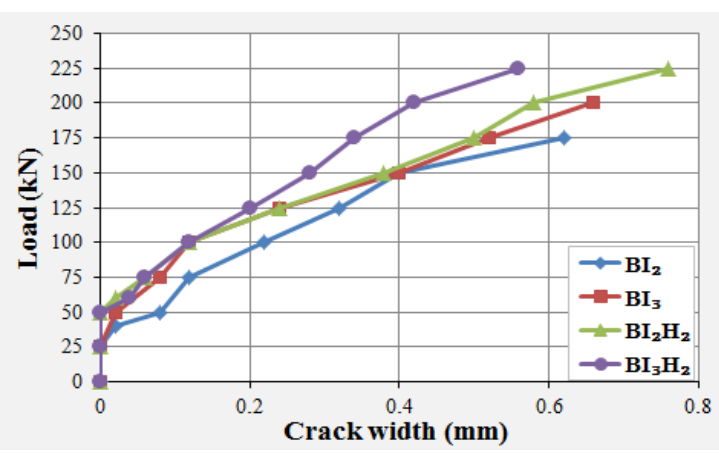

Figure 18. Load versus crack width for group A

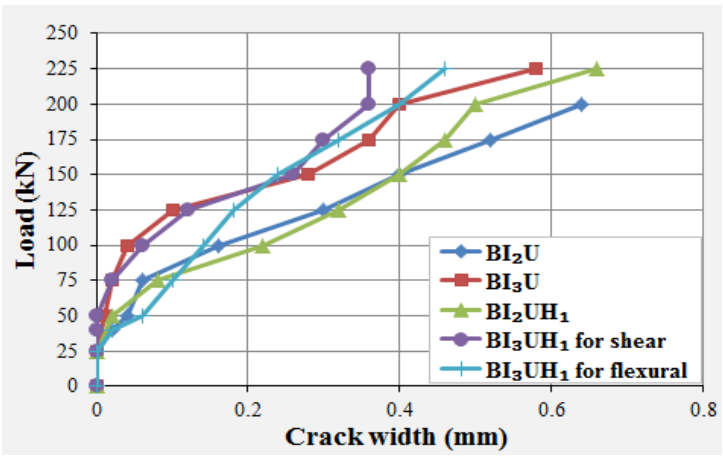

Figure 19. Load versus crack width for group B

\section{Conclusions}

The following points have been reached in this research:

1- Test results confirm that the strengthening technique of CFRP system is applicable and can increase the shear capacity for strengthened SCC of RC beams. In this study, the ultimate load capacity of the strengthened beams ranged between $35 \%$ to $86 \%$ over the ultimate load capacity of the reference beam (BC), while the increase in ultimate loads ranged between (7-10)\% by comparison of wrapping system (two side with U-shape) of CFRP strips.

2- A decrease in the width of cracks due to presence of CFRP sheets is occurs. The average decline is about $83 \%$ of the crack width of the control SCC beams.

3- The inclined U-shape CFRP strips gave better enhancement than the inclined 2-side CFRP strips in ultimate load with the same distribution 
of CFRP strips. The average increase is about $(8.6 \%)$.

4- Experimental tests of the eight SCC beams strengthened by with and without horizontal CFRP strips indicate that the presence of end horizontal CFRP strips increases the shear capacity of the beams by $12.2 \%, 7.62 \%, 9.1 \%$ and $15.1 \%$ for beams with the same properties. This is attributed to the increasing effective length Le of the CFRP strip which works as a link between the top compressive zone and the bottom tension zone. This is similar to the steel stirrups functioning to prevent the propagation and widening the diagonal shear cracks. Therefore, rupturing failure of the horizontal CFRP strips.

\section{References}

1. Al-Mishhadani, S.A. and Al-Rubaie, M.F.,(2009), "A Data Base for Self Compacting Concrete in Iraq", Eng. \& Tech. Journal Vol.27, No.6, PP. 1203-1218.

2. Horta, A., (2005), " MSc. Thesis / Evaluation of Self-Consolidating Concrete for Bridge Structure Applications",Georgia Institute of Technology.

3. Dehn, F., K. Holschemacher, and D. Weisse., (2000), "Self-Compacting Concrete Time Development of the Material Properties and the Bond Behavior", LACER No. 5, pp.115-123.

4. Khayat, K. H., Assad, J. and Daczko, J., (2004), "Comparison of Field - Oriented Test Methods to Assess Dynamic Stability of Self Consolidated Concrete", ACI Materials Journal, Vol.101, No. 2, pp. 168-176.

5. Carolin,A., (2003), " Ph.D. Thesis / Carbon Fiber Reinforced Polymers for Strengthening of Structural Elements", university of Lulea, Sweden.

6. C.W. Dolan, H.R. Hamilton, and A. Nanni, (2001), "Design Recommendations for Concrete Structures Prestressed with FRP Tendons", FHWA Contract, Final Report, Vol. 1, August.

7. B.E. Parth Athawale, (2012), " MSc. thesis / Analysis of Factors Affecting Effective Bond Length for Fiber Reinforced Polymer Composite Laminate Externally Bonded to Concrete Substrate", Texas Technical University, May.

8. ACI Committee 440.2R-08, (2008), "Guide for the Design and Construction of Externally Bonded FRP Systems for Strengthening Concrete Structures", American Concrete Institute, Michigan, USA, July, pp. 80.

9. Khalifa, A.M., (1999), " PhD. Thesis / Shear Performance of Reinforced Concrete Beams Strengthened with Advanced Composites", University of Missouri-Rolla, Center for Infrastructure Engineering Studies (CIES).
10. Sato, Y., Ueda, T., Kakuta, Y., and Tanaka, T., (1996), "Shear Reinforcing Effect of Carbon Fiber Sheet Attached to Side of Reinforced Concrete Beams", Proceedings of The 2nd International Conference on Advanced Composite Materials in Bridges and Structure, ACMBS-II, Montreal, Canada, pp. 621-627.

11. Mohammed, A. S., (2016), " PhD. Thesis / Strengthening of Lightweight Reinforced Concrete Deep Beams with Woven Carbon Fiber Fabric", University of Technology, Iraq.

12. Ali, D. D., (2007), " PhD. Thesis / Experimental and Theoretical Investigation of The Behavior of Reinforced Concrete Beams Strengthened by Fiber Reinforced Polymer", University of Baghdad, College of Engineering, Iraq.

13. Izzet, A. F., (2008), "PhD. Thesis / Retrofit of Shear Critical R.C. Beams with Carbon Fiber Reinforced Polymer Sheets", University of Technology, Iraq.

14. Meshfeq, M-R . M., (2012), " MSc. Thesis / Experimental and Theoretical Investigation of Shear Strengthening of R/C Continuous Beams Using Externally Bonded CFRP Sheets", College of Engineering, University of Babylon, Iraq.

15. Iraqi Specification, No.5, (1984), "Portland cement", Baghdad.

16. Iraqi Specification, No.45, (1984), "Aggregate from natural sources for concrete and construction", Baghdad.

17. ASTM C494/C494M-15, (2015), "Standard Specifications for Chemical Admixtures for Concrete", Developed by ASTM Subcommittee C09.23, Vol. 04.02, West Conshohocken, PA, USA.

18. ASTM A1064/A1064N-14, (2014), "Standard Specifications for Carbon-Steel Wirs and Welded Wire Reinforcement, Plain and Deformed, for Concrete", Developed by ASTM Subcommittee A01.05 on Steel, Stainless Steel, and Related Alloys, Vol.01.04, West Conshohocken, PA, USA.

19. ASTM A615/A615M-15a, (2015), "Standard Specifications for Deformed and Plane CarbonSteel Bars for Concrete Reinforcement," Developed by ASTM Subcommittee A01.05 on Steel, Stainless Steel, and Related Alloys, Vol. 01.04, West Conshohocken, PA, USA.

20. EFNARC, (2005): European Federation Dedicated to Specialist Construction Chemicals and Concrete systems "The European Guidelines for Self-Compacting Concrete Specification, Production and Use", pp. 68. 